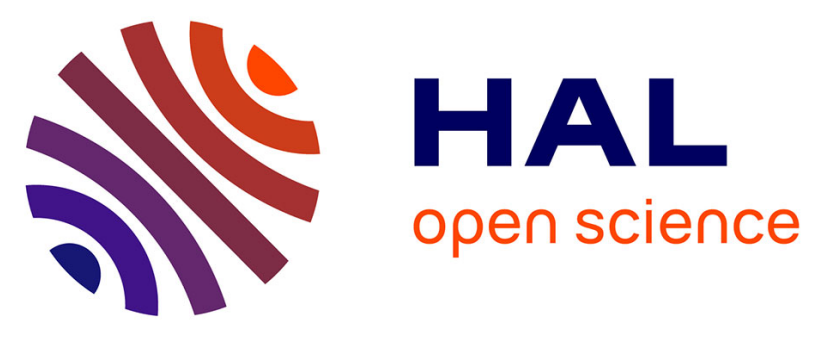

\title{
Synthesis of ferrocene amides and esters from aminoferrocene and 2-substituted ferrocenecarboxylic acid and properties thereof
}

\author{
Palabindela Srinivas, Sunchu Prabhakar, Floris Chevallier, Ekhlass Nassar, \\ William Erb, Vincent Dorcet, Viatcheslav Jouikov, Palakodety Radha \\ Krishna, Florence Mongin
}

\section{To cite this version:}

Palabindela Srinivas, Sunchu Prabhakar, Floris Chevallier, Ekhlass Nassar, William Erb, et al.. Synthesis of ferrocene amides and esters from aminoferrocene and 2-substituted ferrocenecarboxylic acid and properties thereof. New Journal of Chemistry, 2016, 40 (11), pp.9441-9447. 10.1039/c6nj02018f . hal-01414285

HAL Id: hal-01414285

https://hal-univ-rennes1.archives-ouvertes.fr/hal-01414285

Submitted on 17 Feb 2017

HAL is a multi-disciplinary open access archive for the deposit and dissemination of scientific research documents, whether they are published or not. The documents may come from teaching and research institutions in France or abroad, or from public or private research centers.
L'archive ouverte pluridisciplinaire HAL, est destinée au dépôt et à la diffusion de documents scientifiques de niveau recherche, publiés ou non, émanant des établissements d'enseignement et de recherche français ou étrangers, des laboratoires publics ou privés. 


\title{
Synthesis of ferrocene amides and esters from aminoferrocene and 2-substituted ferrocenecarboxylic acid and the properties thereof
}

\author{
Palabindela Srinivas, ${ }^{\mathrm{a}, \mathrm{b}}$ Sunchu Prabhakar, ${ }^{\mathrm{a}, \mathrm{b}}$ Floris Chevallier, ${ }^{\mathrm{a}}$ Ekhlass Nassar, ${ }^{\mathrm{c}}$ William Erb, ${ }^{{ }^{\mathrm{a}}}$ \\ Vincent Dorcet, ${ }^{d}$ Viatcheslav Jouikov, ${ }^{* a}$ Palakodety Radha Krishna* ${ }^{* b}$ and Florence Mongin ${ }^{a}$ \\ Different ferrocenecarboxamides were synthesized from aminoferrocene and various acid coupling partners such as $N_{\alpha}{ }^{-}$ \\ Boc-L-tryptophan and $N$-protected sugar amino acids ( $N$-Boc-3-amino-3-deoxy-1,2-O-isopropylidene- $\alpha$-D-ribofuranoic acid, \\ $N$-Boc-3-amino-3-deoxy-1,2-O-isopropylidene- $\alpha$-D-xylofuranoic acid and their corresponding homo- and hetero-dimers). \\ Similarly, reactions between 2-aminoethyl ferrocenecarboxylate and $\mathrm{N}$-protected sugar amino acids afforded compounds \\ with a carboxamide functional group remotely positioned from the ferrocene core. The X-ray diffraction structure of one \\ of them showed the presence of an intermolecular hydrogen bond between the amide functional groups. Carbonylamino \\ (or carbonyloxy) and oxycarbonyl 1,2-disubstituted ferrocenes were prepared either as racemic mixtures or in \\ enantiomerically pure $\left(S_{\mathrm{P}}\right)$ form. Their electrochemical evaluation revealed distinctive features. Interestingly, the \\ enantiomerically pure ferrocene diester showed a large potential shift ( $+45 \mathrm{mV}$ ) in the presence of L-glutamic acid. Finally, \\ some of the synthesized ferrocenes were evaluated for their antibacterial, antifungal and antiproliferative (MCF-7) \\ activities.
}

\section{Introduction}

As a redox-active molecule, ferrocene has fascinated scientists for its applications in fields such as materials science and medicinal chemistry. The incorporation of ferrocenes in peptides $^{1}$ and carbohydrates ${ }^{2}$ in order to achieve new properties has grown rapidly in the last few decades. Such scaffolds also proved to be bactericidal and fungicidal, ${ }^{3}$ as well as endowed with cytotoxic ${ }^{3 c, 4}$ activities. Besides, ferrocenes bearing amino acid chains at their $1,1^{\prime}$-positions can exhibit hydrogen bonds, hydrophobic interactions and specific

\footnotetext{
a. Chimie et Photonique Moléculaires, Institut des Sciences Chimiques de Rennes, UMR 6226, Université de Rennes 1-CNRS, Bâtiment 10A, Case 1003, Campus de Beaulieu, 35042 Rennes, France. E-mails: floris.chevallier@univ-rennes1.fr, william.erb@univ-rennes1.fr (corresponding author), viatcheslav.jouikov@univrennes1.fr

b. Organic \& Biomolecular Chemistry Division, CSIR-Indian Institute of Chemical Technology, D-211, Discovery Laboratory, Hyderabad-500007, India. E-mail: prkgenius@iict.res.in

c. Chemistry Department, Faculty of Women for Arts, Science and Education, Ain

Shams University, 11566 Cairo, Egypt. E-mail: ekhlass_nassar@hotmail.com

d. Centre de Diffractométrie $X$, Institut des Sciences Chimiques de Rennes, UMR 6226, Université de Rennes 1-CNRS, Bâtiment 10B, Campus de Beaulieu, 35042 Rennes, France.

+ Electronic supplementary information (ESI) available: Experimental procedures and characterization of the compounds, ${ }^{1} \mathrm{H}$ and ${ }^{13} \mathrm{C}$ NMR spectra of the new compounds, and X-ray crystallographic data. CCDC 1475360 (FcE-1). See DOI: $10.1039 / x 0 x x 00000 x$

conformations, and have therefore been the purpose of
}

structural investigations. ${ }^{5}$ Due to their ideal electrochemical properties, ferrocene derivatives are also considered as good candidates for incorporation in sensors. ${ }^{1 \mathrm{c}, 2 \mathrm{a}, 6}$ Consequently, several research publications are devoted to the synthesis of functionalized ferrocenes, ${ }^{7}$ and notably when linked to biomolecules. $^{8}$

With the aim of identifying suitable scaffolds either for molecular recognition or endowed with bioactivities, we embarked on the synthesis of new ferrocene derivatives. Herein, we notably describe the synthesis of monosubstituted ferrocenes containing fragments based on 3-deoxy-1,2-Oisopropylidene- $\alpha$-D-ribofuranose, 3-deoxy-1,2-Oisopropylidene- $\alpha$-D-xylofuranose and 1,2:5,6-di- $O$ isopropylidene- $\alpha$-D-glucofuranose, and of 1,2-disubstituted ferrocenes. While electrochemistry was carried out on various ferrocene esters, structure determination by X-ray diffraction proved possible in one case. Furthermore, numerous synthesized ferrocene amides and esters were screened for their antibacterial and antifungal activity, as well as their antiproliferative potential against MCF-7.

\section{Results and discussion}

\section{Synthesis}

We first considered the access to $N$-functionalized aminoferrocenes. Towards this purpose, aminoferrocene (1) 
was prepared by (i) deprotometalation of ferrocene ${ }^{9}$ followed by iodolysis, ${ }^{10}$ and (ii) treatment of the iodide with phthalimide in the presence of $\mathrm{Cu}_{2} \mathrm{O}$ in acetonitrile followed by deprotection. ${ }^{11}$ Peptidic coupling was next performed in the presence of 1-hydroxybenzotriazole (HOBt) and 1-ethyl-3-(3dimethylaminopropyl)carbodiimide $(E D C l)^{12}$ from 1 by using $\mathrm{N}_{\alpha}$-Boc-L-tryptophan (Boc-Trp-OH), the ( $N$-protected) Sugar Amino Acids (SAA) N-Boc-3-amino-3-deoxy-1,2-Oisopropylidene- $\alpha$-D-ribofuranoic acid (SAA-1) and N-Boc-3amino-3-deoxy-1,2-O-isopropylidene- $\alpha$-D-xylofuranoic acid (SAA-2), as well as the corresponding homodimers (SAA-3 and SAA-4) and heterodimer (SAA-5) as partners, to afford the respective Ferrocene Carboxamides FcC-0 to FcC-5 in yields ranging from 60 to $66 \%$ (Table 1). Further, amine deprotection of FcC-0 by trifluoroacetic acid (TFA) and peptidic coupling with Boc-Trp-OH provided FcC-6 in 63\% yield (Scheme 1).

We next turned to sugar-based derivatives of ferrocenecarboxylic acid. Prepared by esterification using $N$ Boc ethanolamine and ferrocenecarboxylic acid, 2-(tertbutoxycarbonylamino)ethyl ferrocenecarboxylate ${ }^{13}$ underwent amine deprotection followed by peptidic coupling with $\mathrm{N}$-Boc3-amino-3-deoxy-1,2-O-isopropylidene- $\alpha$-D-ribofuranoic acid (SAA-1) and $N$-Boc-3-amino-3-deoxy-1,2-O-isopropylidene- $\alpha$ D-xylofuranoic acid homodimer (SAA-4) to respectively furnish the Ferrocene Esters FcE-1 (65\% yield) and FcE-4 (62\% yield) (Scheme 2, Figure 1).

The intermolecular hydrogen bond detected between amide functions in the case of FcE-1 led us to synthesize other 2-substituted ferrocenecarboxylic derivatives. We chose 2iodoferrocenecarboxylic acid (7, Scheme 3) as the starting material. Thus, ( \pm )-2-iodoferrocenecarboxylic acid (rac-7) was generated from methyl ferrocenecarboxylate by (i) deprotonative metalation using the mixed lithium-zinc base in situ prepared from $\mathrm{ZnCl}_{2} \cdot$ TMEDA (0.5 equiv) and LiTMP (TMP = 2,2,6,6-tetramethylpiperidino, 1.5 equiv) in $\mathrm{THF}$ ( $\mathrm{THF}=$
Table 1 Synthesis of the Ferrocene Carboxamides FcC-0 to FcC-5.

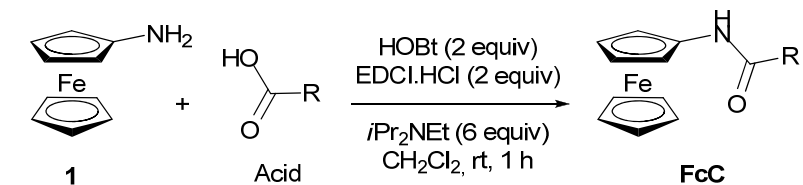

Entry Acid $\quad-\mathrm{R}$

$1 \quad$ Boc-Trp-OH

FcC-0, 66

SAA-1<smiles>CCC(Cc1c[nH]c2ccccc12)NC(=O)OCc1ccccc1</smiles>

FCC-0, 66

FcC-1, 62

3

SAA-2

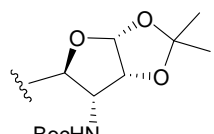

4

SAA-3

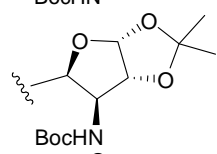

FcC-2, 60<smiles>CCCO[C@H]1OC(C)(C)O[C@@H]1O</smiles><smiles>[R6]SC(F)(F)F</smiles>

5

SAA-4<smiles>CCCCC(=O)N[C@@H]1C(C)O[C@@H]2OC(C)(C)O[C@H]21</smiles>

FcC-4, 63

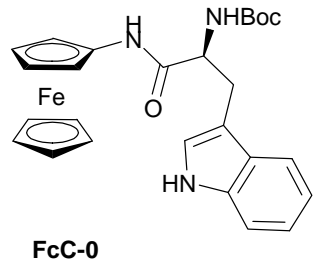

FcC-0

Scheme 1 Synthesis of the Ferrocene Carboxamide FcC-6
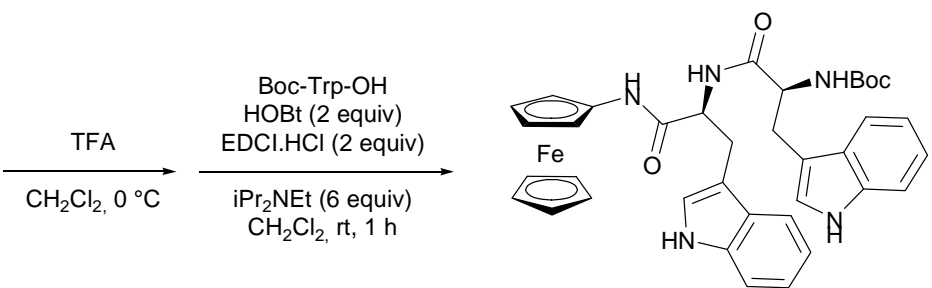

FcC-6, 63\% yield

tetrahydrofuran) at room temperature followed by iodolysis as described previously, ${ }^{14}$ and (ii) saponification of the ester. 

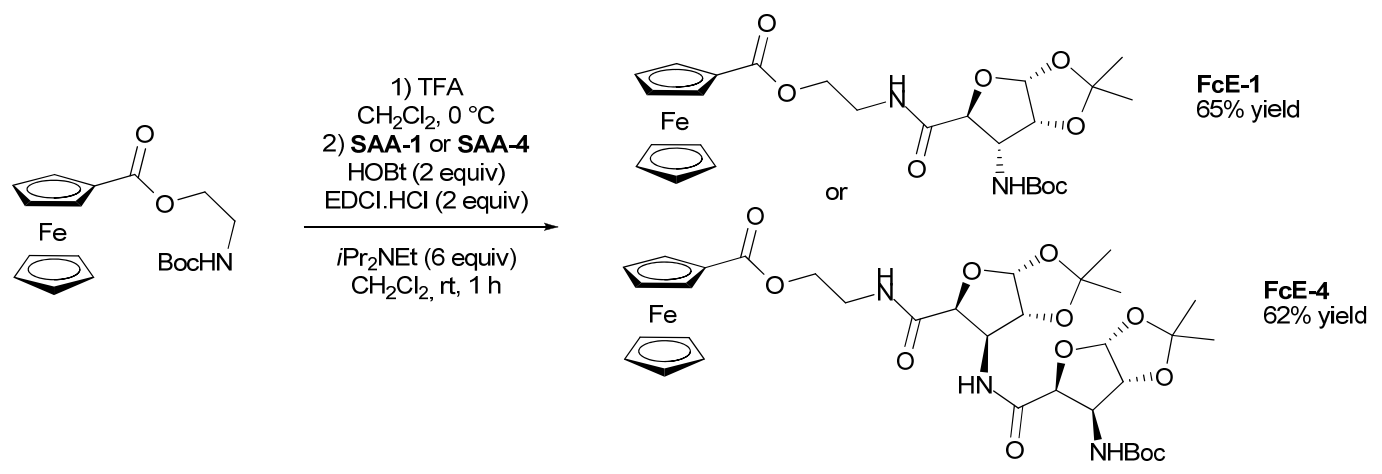

Scheme 2 Synthesis of the Ferrocene Esters FcE-1 and FcE-4.
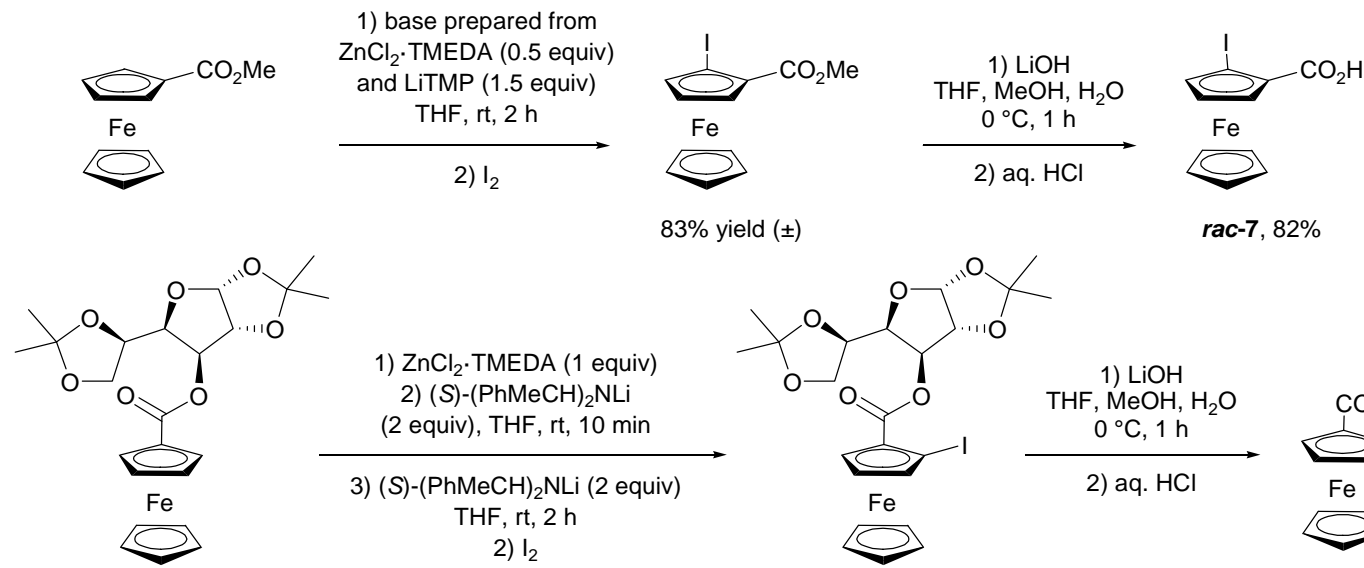
1) $\mathrm{ZnCl}_{2} \cdot \mathrm{TMEDA}$ (1 equiv) 2) $(\mathrm{S})-(\mathrm{PhMeCH})_{2} \mathrm{NLi}$ (2 equiv), THF, rt, $10 \mathrm{~min}$
3) $(\mathrm{S})-(\mathrm{PhMeCH})_{2} \mathrm{NLi}$ (2 equiv) THF, rt, $2 \mathrm{~h}$ 2) $\mathrm{I}_{2}$

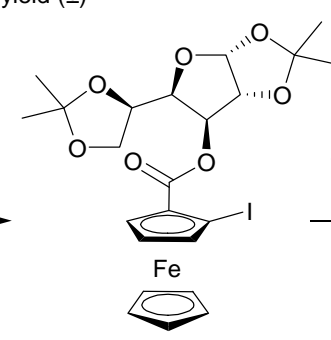

$85 \%$ yield $\left(S_{\mathrm{P}}\right)$
1) $\mathrm{LiOH}$

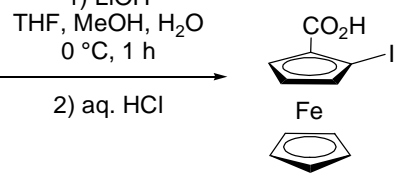

$S_{\mathrm{P}}-7,80 \%$

Scheme 3 Synthesis of 2-iodoferrocenecarboxylic acid either as a racemic mixture (rac-7, top) or enantiomerically pure $\left(\boldsymbol{S}_{\mathrm{p}}-\mathbf{7}\right.$, bottom).

6

SAA-5

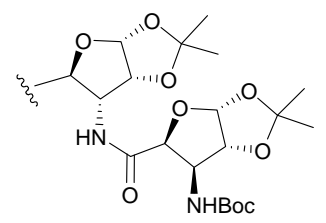

FcC-5, 63

${ }^{a}$ Yield after purification by column chromatography.

Corresponding $S_{\mathrm{P}}$-2-iodoferrocenecarboxylic acid $\left(\boldsymbol{S}_{\mathrm{P}}-7\right)^{15}$ isopropylidene- $\alpha$-D-glucofuranose by (i) deprotonative metalation in THF using lithium (S)-bis(1-phenylethyl)amide (2 $\times 2$ equiv at $10 \mathrm{~min}$ interval) through a double asymmetric induction process in the presence of $\mathrm{ZnCl}_{2} \cdot \mathrm{TMEDA}$ ( 1 equiv) as in situ trap, followed by iodolysis as described previously, ${ }^{16}$ and (ii) saponification of the ester.

was synthesized from 3-O-(ferrocenecarbonyl)-1,2:5,6-di-O-

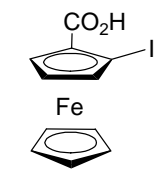

rac-7 or $S_{\mathrm{p}-7}$

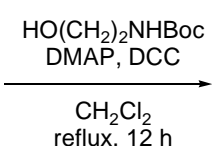

reflux, $12 \mathrm{~h}$

Scheme 5 Synthesis of ferrocene dieste $\frac{\mathbf{1 1 3}}{\mathrm{C} 35}$ either as racemic mixture or enantiomerically pure.

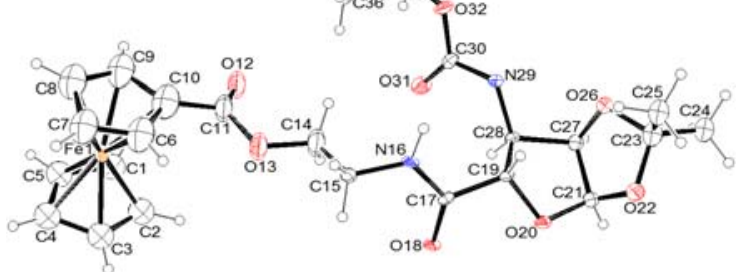

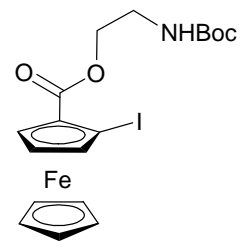

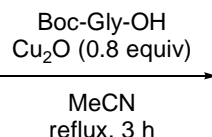

reflux, $3 \mathrm{~h}$ rac-10 or $S_{\mathrm{p}}-10$

iomerically pure.

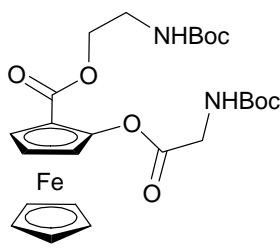

rac-11 or $\mathrm{S}_{\mathrm{P}}-11$

20 -11 or $s^{2}$
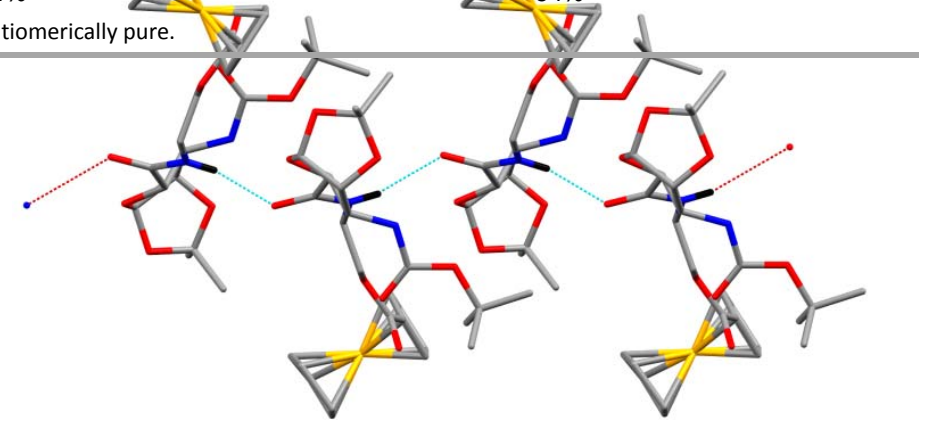

Fig. 1 Left: ORTEP diagram (30\% probability) of FcE-1. Right: visualization of the intermolecular hydrogen bond (2.996 Å); H atoms bound to C atoms are omitted for clarity. 
Both 2-substituted ferrocenecarboxamides rac-8 and $S_{\mathrm{p}}-\mathbf{8}$ were synthesized in $84 \%$ yield, respectively from rac-7 and $\boldsymbol{S}_{\mathrm{P}^{-}}$ 7 , by $\mathrm{HOBt} / \mathrm{EDCl}$-mediated peptidic coupling ${ }^{12}$ using ethyl glycinate hydrochloride $(\mathrm{H}-\mathrm{Gly}-\mathrm{OEt} . \mathrm{HCl})$ as partner. Treatment with $\mathrm{N}$-protected glycine Boc-Gly-OH in the presence of $\mathrm{Cu}_{2} \mathrm{O}$ at acetonitrile reflux ${ }^{11}$ led to the substitution products rac-9 and $\boldsymbol{S}_{\mathbf{P}}-\mathbf{9}$ in $\mathbf{5 0 \%}$ yield (Scheme 4 ).

Ferrocene diesters rac-11 and $\boldsymbol{S}_{\mathrm{p}} \mathbf{- 1 1}$ were similarly obtained by substitution from respectively rac-10 and $S_{\mathrm{p}}-10$ after esterification of rac-7 and $\boldsymbol{S}_{\mathrm{p}-7} \mathbf{7}$ with $\mathrm{N}$-Boc ethanolamine under classical conditions (Scheme 5). ${ }^{17}$

\section{Electrochemistry}

The synthesized ferrocene conjugates being redox-active, we explored the electrochemical properties of FcE-1, FcE-4, rac-9, $S_{\mathrm{P}}-\mathbf{9}$, rac-11 and $S_{\mathrm{P}}-\mathbf{1 1}$ by voltammetry aiming to explore the suitability of this analytical method for the study of their behavior and intermolecular interactions with biomolecules.

Being oxidized at a glassy carbon (GC) disk electrode in $\mathrm{CH}_{3} \mathrm{CN} / 0.1 \mathrm{M} \mathrm{Bu}_{4} \mathrm{NBF}_{4}$, all these ferrocene derivatives show reversible oxidation signals (Figure 2 ) with $\mathrm{E}_{0}$ slightly superior to that of non-substituted ferrocene ( $0.31 \mathrm{~V}$ vs SCE ${ }^{18}$, Table 2$)$. Their peak currents $i_{\mathrm{p}}$ are proportional to the substrate concentration while $i_{\mathrm{p}} / v^{1 / 2}$ is invariant with the scan rate, attesting diffusional character of the process. $^{19}$ From comparison with the $i_{\mathrm{p}}$ of one-electron oxidation of ferrocene, ${ }^{20}$ the electron stoichiometry was found to be $n=1$ in all cases.
Figure 2 Voltammetry of rac-11 $\left(2 \mathrm{mmol} \mathrm{L}^{-1}\right)$ alone (black), and the shift of its oxidation signal (grey) in the presence of L-glutamic acid (1, 2, 3 and 8 equiv) at a $\mathrm{GC}$ disk electrode in $\mathrm{CH}_{3} \mathrm{CN} / 0.1 \mathrm{M} \mathrm{Bu}_{4} \mathrm{NBF}_{4}$. Scan rate $v=200 \mathrm{mV} \mathrm{s}^{-1} . \mathrm{T}=22{ }^{\circ} \mathrm{C}$.

Interestingly, the voltammogram of racemic rac-9 looks different compared to other curves in this series (Figure 3, a). First derivative voltammogram allows distinguishing two close electron transfers (each with $\mathrm{n} \cong 0.5$ ) with $36 \mathrm{mV}$ difference between $\mathrm{E}_{0}{ }^{1}$ and $\mathrm{E}_{0}{ }^{2}$ (Figure $\left.3, \mathrm{~b}\right)$. First oxidation of rac-9 $\left(\mathrm{E}_{0}{ }^{1}=\right.$ $0.385 \mathrm{~V}$ ) occurs at practically same potential as that of pure $S_{\mathrm{P}}$ $9\left(E_{0}=0.380 \mathrm{~V}\right)$ suggesting that it is related to the electron withdrawal from the same stereoisomer; second step at slightly more positive potentials thus corresponds to the oxidation of its enantiomer $\left(\boldsymbol{R}_{\mathrm{P}}-\mathbf{9}\right)$ present in the 50:50 ratio. It is to note that in the pair rac-11 and $\boldsymbol{S}_{\mathrm{p}} \mathbf{- 1 1}$ this feature is not observed. Since the ferrocene derivatives rac-11 and $S_{\mathrm{P}}-\mathbf{1 1}$ are 1,2-carboxy-substituted while rac-9 and $\boldsymbol{S}_{\mathbf{p}}-\mathbf{9}$ have an amidosubstituent in place of one carboxy group, one can suppose that some intramolecular $\mathrm{NH} \cdots \mathrm{O}=\mathrm{C}$ coordination via an 8membered cyclic structure might account for this; the fact that both oxidations (at $\mathrm{E}_{0}{ }^{1}$ and $\mathrm{E}_{0}{ }^{2}$ ) of rac-9 and $\boldsymbol{S}_{\mathrm{p}}-\mathbf{9}$ occur at less positive potentials than those of rac-11 and $S_{\mathrm{p}}-\mathbf{1 1}$ (Table 2) is probably also related to this difference.

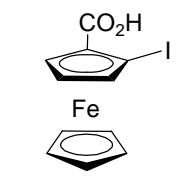

rac-7 or $S_{\mathrm{P}^{-7}}$

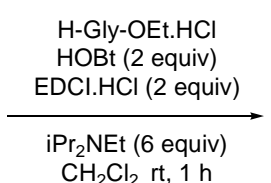

$\mathrm{CH}_{2} \mathrm{Cl}_{2}, \mathrm{rt}, 1 \mathrm{~h}$
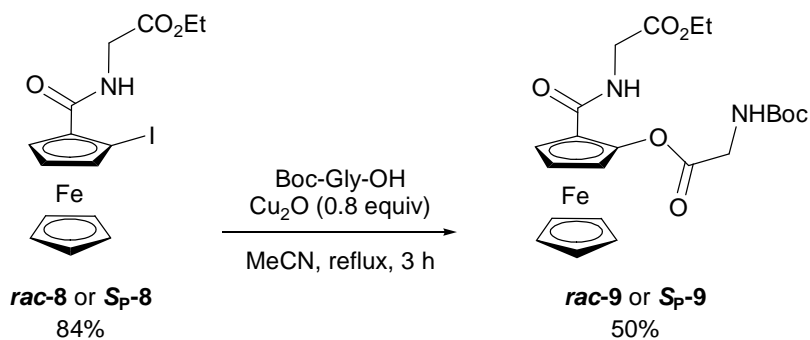

Scheme 4

Synthesis of 2-substituted ferrocenecarboxamides $\mathbf{8}$ and $\mathbf{9}$ either as racemic mixtures or enantiomerically pure.

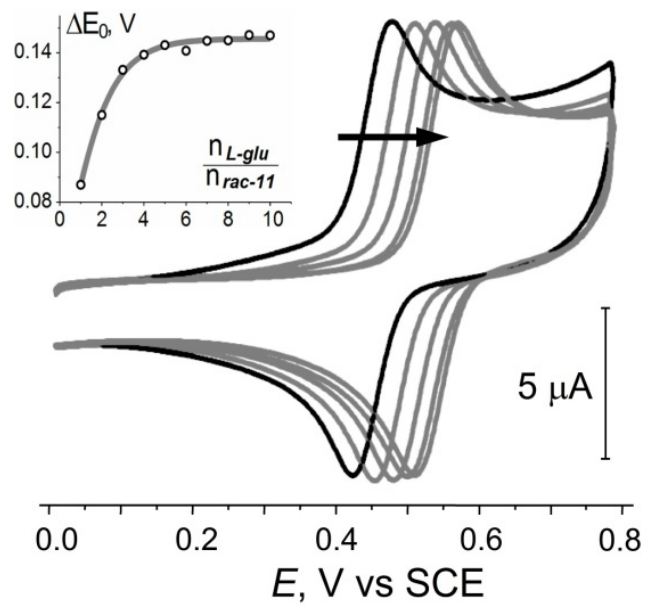




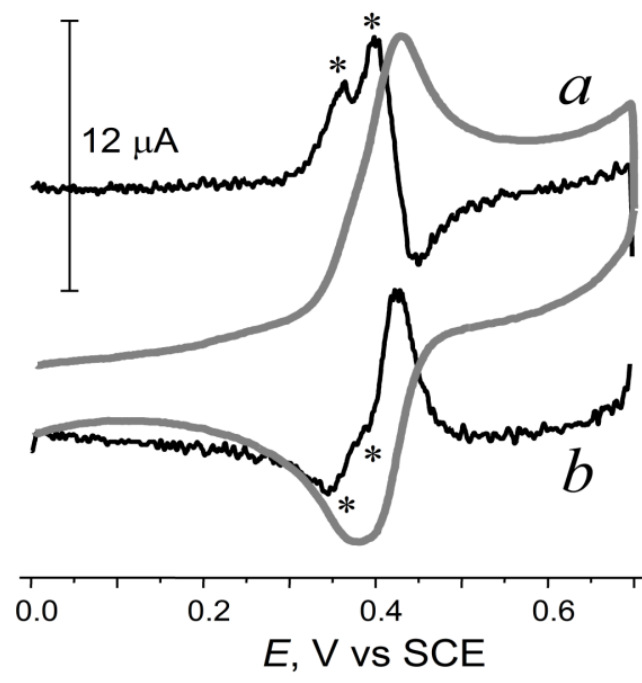

Figure 3 (a, grey) Cyclic voltammogram of rac-9 $\left(2 \mathrm{mmol} \mathrm{L}^{-1}\right)$ at a glassy carbon (GC) disk electrode in $\mathrm{CH}_{3} \mathrm{CN} / 0.1 \mathrm{M} \mathrm{Bu}_{4} \mathrm{NBF}_{4}$. (b, black) First derivative; two redox pairs are marked with asterisks. $v=200 \mathrm{mV} \mathrm{s}^{-1} . \mathrm{T}=22{ }^{\circ} \mathrm{C}$.

Table 2 Oxidation potentials of substituted ferrocenes. ${ }^{a}$

\begin{tabular}{lll}
\hline \multicolumn{2}{l}{ Compound } & $\mathrm{E}_{0}, \mathrm{~V}$ vs SCE \\
\hline 1 & FcE-1 & 0.355 \\
2 & FcE-4 & 0.395 \\
3 & rac-9 & $0.385,0.420$ \\
4 & $S_{\mathrm{P}-9}$ & 0.380 \\
5 & rac-11 & 0.435 \\
6 & $S_{\mathrm{P}-11}$ & 0.390 \\
${ }^{a} \mathrm{GC}$ electrode, $\mathrm{CH}_{3} \mathrm{CN} / 0.1 \mathrm{M} \mathrm{Bu}_{4} \mathrm{NBF}_{4} \cdot \mathrm{v}=$ & $100 \mathrm{mV} \mathrm{s}^{-1}$. \\
\hline
\end{tabular}

All ferrocene derivatives were systematically oxidized in the presence of a number of amino acids (L-alanine, Lphenylalanine, L-proline, L-glutamic acid, L-aspartic acid, $\mathrm{N}-\alpha$ acetyl-L-histidine and trans-4-hydroxy-L-proline) that might possibly be complementary to their peptide chains. Although some alteration of the oxidation potentials $E_{0}$ was in fact observed, e.g. for FcE-1, rac-9 and $\boldsymbol{S}_{\mathrm{p}-9} \mathbf{9}$, the $\Delta \mathrm{E}_{0}$ values were not large enough to serve as a reliable analytical signal. For instance, $S_{\mathrm{P}}-\mathbf{9}$ showed $\Delta \mathrm{E}_{0}$ of $+25,+12$ and $+10 \mathrm{mV}$ in the presence of L-glutamic acid, L-histidine and L-phenylalanine, respectively; for rac-11, maximal value of $\Delta \mathrm{E}_{0}=+20 \mathrm{mV}$ was observed in the presence of L-phenylalanine. At the same time, FCE-4 did not show any shift in $E_{0}$ within the experimental uncertainty $\left(\Delta \mathrm{E}_{0} \cong 5 \mathrm{mV}\right)$.

In contrast, $S_{\mathrm{P}}-\mathbf{1 1}$ and rac-11 reveal a pronounced shift of $\mathrm{E}_{0}$ (Figure 2) upon addition of L-glutamic acid. Its maximal value (for rac-11, $\Delta \mathrm{E}_{0}=140 \mathrm{mV}$ ) is attained at the molar ratio superior to $1: 1$ (Figure 2, inset) indicating some dynamic equilibrium between the complexed and free forms in the solution. At this point, the origin of such important shift in the presence of L-glutamic acid is not yet clear. Nevertheless, on the basis of precedents in the literature concerning binding properties of 1,1'- and 1,3-disubstituted ferrocenes and their impact on the oxidation $\mathrm{E}_{0},{ }^{21}$ a more important inductive effect of the ferrocene substituents, due to $\boldsymbol{S}_{\mathbf{P}}-\mathbf{1 1}$ acting as a polytopic ligand, could be advanced to rationalize this result.

\section{Biological evaluation}

The synthesized Ferrocene Carboxamides FcC-0 to FcC-3, FcC-5 and FcC-6, and Ferrocene Esters FcE-1 and FcE-4 were screened for their antibacterial activity against Gram-negative (Escherichia coli) and Gram-positive (Staphylococcus aureus) bacteria, and for their antifungal activity against Candida albicans (Table 3). The tested compounds were found to have a moderate effect against Gram-negative bacteria (E. coli) except in the case of FcE-4 for which an activity similar to that of ciprofloxacin was detected. A moderate effect was similarly noted against Gram-positive bacteria (Staphylococcus aureus) for most of the compounds evaluated; in the case of FcC-1 and FCE-4, an activity similar to that of ciprofloxacin was observed. For their antifungal activity, FcE-1 and FcE-4 gave the best results against Candida albicans when compared with the reference drug (nystatin).

Table 3 Bactericidal and fungicidal activity of the compounds FCC-0 to FcC-3, FcC-5, FcC-6, FcE-1, FcE-4, ciprofloxacin and nystatin. ${ }^{a}$

\begin{tabular}{llll}
\hline Compound & $\begin{array}{l}\text { Escherichia } \\
\text { coli }\end{array}$ & $\begin{array}{l}\text { Staphylococcus } \\
\text { aureus }\end{array}$ & $\begin{array}{l}\text { Candida } \\
\text { albicans }\end{array}$ \\
\hline FcC-0 & +++ & ++ & ---- \\
FCC-1 & +++ & ++++ & ++ \\
FCC-2 & ++ & +++ & ---- \\
FCC-3 & +++ & ++ & ++ \\
FCC-5 & ++ & ++ & --- \\
FCC-6 & ++ & +++ & --- \\
FCE-1 & ++ & +++ & ++++ \\
FcE-4 & ++++ & ++++ & ++++ \\
Ciprofloxacin & ++++ & ++++ & ---- \\
nystatin & ---- & ---- & ++++
\end{tabular}

${ }^{a}$ The diameters of zones of inhibition are given in $\mathrm{mm}$. Stock solution: $5 \mu \mathrm{g}$ in 1 $\mathrm{mL}$ of DMF; $0.1 \mathrm{~mL}$ of stock solution in each hole of each paper disk. $+:<15 \mathrm{~mm}$; ++: 15-24 mm; +++: 25-34 mm; ++++: 35-44 mm, etc.

A study has also been carried out to investigate the cytotoxic potential of the derivatives FcC-0 to FcC-3 and FcC-6 (Table 4). The antiproliferative activity of the derivatives was determined using breast cancer cell line MCF-7, which is an invasive differentiated mammary epithelial breast cancer cell line used worldwide to screen and compare the antiproliferative activity of new molecules vs standard anticancer compounds. The compounds FcC-1 and FcC-2 showed low activity while FcC-0, FcC-3 and FcC-6 were found to be more effective and exhibited an activity slightly lower than that of the reference standard doxorubicin. The compounds FcC-0 and FcC-6, made from $N_{\alpha}$-Boc-L-tryptophan, proved more active than the sugar-based derivatives. 
Table 4 Cytotoxic activity of the compounds FcC-0 to FcC-3, FcC-6 and doxorubicin against MCF-7. ${ }^{a}$

\begin{tabular}{ll} 
Compound & $\mathrm{IC}_{50}(\mu \mathrm{g} / \mathrm{mL})$ \\
\hline FcC-0 & 4.6 \\
FcC-1 & 11.3 \\
FcC-2 & 10.0 \\
FcC-3 & 6.0 \\
FcC-6 & 4.4 \\
doxorubicin & 3.5 \\
& \\
${ }^{a}$ IC50 is defined as the concentration which results in a 50\% decrease in the cell \\
number as compared with that of the control structures in the absence of an \\
inhibitor.
\end{tabular}

\section{Conclusions}

Various ferrocene-based amides and esters were synthesized and screened for their antibacterial and antifungal activity, as well as their cytotoxic potential against MCF-7. All the ferrocene derivatives studied by voltammetry exhibit reversible oxidation at close potentials reflecting quite weak (inductive) influence of the substituent on the redox-active ferrocene unit. Quite surprisingly, two stereoisomers of racemic rac-9 in the acetonitrile solution show close but distinct individual oxidation steps of their ferrocene units while those of rac-11 are not redox-distinguishable. In general, analytical response of ferrocene as redox marker in these molecules is not specific to external amino acids. If one cannot expect strong variation in oxidation $E_{0}$ with single coordination (no strong variation of the electronic effects of the substituents, neither difference in diffusion coefficients), things might be different with ditopic ligands. ${ }^{21}$ The specific response of $\boldsymbol{S}_{\mathrm{P}} \mathbf{- 1 1}$ for the presence of L-glutamic acid certainly merits further consideration.

\section{Experimental}

\section{General}

All reagents were obtained commercially unless otherwise noted. All reactions were performed in oven-dried glassware (Schlenk tubes) under an argon atmosphere (Air Liquide). All solvents were dried and distilled by standard procedures. Flash column chromatography separations were achieved on silica gel (Merck-Geduran Si 60, 63-200 $\mu \mathrm{m}$ ).

3-Amino-3-deoxy- $N$-(tert-butoxycarbonyl)-1,2-O-

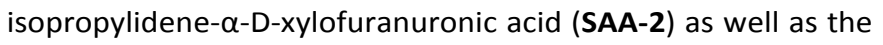
N-Boc protected furanoid sugar amino acids SAA-3 and SAA-5 were prepared as described previously. ${ }^{22}$

Melting points were measured on a Kofler apparatus. Optical rotations were measured on a Perkin Elmer 341 polarimeter $(\lambda=589 \mathrm{~nm})$. Nuclear magnetic resonance spectra were acquired on a Bruker Avance III 300 (300 and $75 \mathrm{MHz}$ for ${ }^{1} \mathrm{H}$ and ${ }^{13} \mathrm{C}$, respectively) spectrometer. Chemical shifts $(\delta)$ in ppm were referenced to the solvent residual peak $\left({ }^{1} \mathrm{H}\right)$ or to the central peak of the solvent signal $\left({ }^{13} \mathrm{C}\right) .{ }^{23}$ High-resolution mass spectra were recorded on Micromass MS/MS ZABSpecTOF and Bruker MicrOTOF-Q II mass spectrometers.

X-ray data of compound FcE-1 were collected with graphite monochromatized Mo-K $\alpha$ radiation $(\lambda=0.71073 \AA$ ) $)$ at $T=$ 150(2) K using D8 VENTURE Bruker AXS diffractometer. The structure was solved by direct methods using the SIR97 program, ${ }^{24}$ and then refined with full-matrix least-square methods based on $F^{2}$ (SHELX-97). ${ }^{25}$ All non-hydrogen atoms were refined with anisotropic atomic displacement parameters. $\mathrm{H}$ atoms were finally included in their calculated positions. Molecular diagrams were generated by ORTEP-3 (version 2.02). ${ }^{26}$

Cyclic voltammetry has been carried out using a PAR 263 potentiostat in a standard $15 \mathrm{~mL}$ three-electrode cell fitted with a glassy carbon disk $(2.5 \mathrm{~mm})$ working electrode, Pt wire as a counter electrode and a saturated calomel electrode separated from the analyte by an electrolytic bridge filled with the same solution $\left(\mathrm{CH}_{3} \mathrm{CN} / 0.1 \mathrm{M} \mathrm{Bu}_{4} \mathrm{NBF}_{4}\right) . \mathrm{CH}_{3} \mathrm{CN}$ (Aldrich) was distilled from $\mathrm{CaH}_{2}$ and the supporting salt $\mathrm{Bu}_{4} \mathrm{NBF}_{4}$ (Acros) was used as received.

\section{General procedure for peptidic coupling ${ }^{12}$}

To a stirred, cooled $\left(0^{\circ} \mathrm{C}\right)$ solution of carboxylic acid (1.0 $\mathrm{mmol}$ ) in $\mathrm{CH}_{2} \mathrm{Cl}_{2}(5 \mathrm{~mL})$ were successively added $\mathrm{HOBt}$ ( $270 \mathrm{mg}$, $2.0 \mathrm{mmol}$ ) and $\mathrm{EDCl}$ hydrochloride $(383 \mathrm{mg}, 2.0 \mathrm{mmol})$. After $15 \mathrm{~min}, \mathrm{a}$ solution of amine $(1.0 \mathrm{mmol})$ and $\mathrm{N}, \mathrm{N}$ diisopropylethylamine $(775 \mathrm{mg}, 6.0 \mathrm{mmol})$ in $\mathrm{CH}_{2} \mathrm{Cl}_{2}(5 \mathrm{~mL})$ was added to the reaction mixture. The reaction was stirred for $1 \mathrm{~h}$ at room temperature before addition of an aqueous saturated solution of $\mathrm{NH}_{4} \mathrm{Cl}(20 \mathrm{~mL})$ and $\mathrm{CHCl}_{3}(20 \mathrm{~mL})$. The organic layer was successively washed with $1 \mathrm{M} \mathrm{HCl}(20 \mathrm{~mL})$, water $(20 \mathrm{~mL})$, aqueous saturated solution of $\mathrm{NaHCO}_{3}(20 \mathrm{~mL})$, dried over $\mathrm{MgSO}_{4}$, filtered and concentrated under reduced pressure.

In vitro antimicrobial and antifungal activity, and cytotoxicity

The assays were performed as reported previously. ${ }^{27}$

\section{Acknowledgments}

We gratefully acknowledge Rennes Métropole, Université de Rennes 1 and CNRS for financial support given to P.S. and S.P. We thank Thermo Fischer for generous gift of 2,2,6,6tetramethylpiperidine. V. D. thanks FEDER (D8 VENTURE Bruker AXS diffractometer). F.M. also thanks the Institut Universitaire de France. This research has been performed as part of the Indo-French 'Joint Laboratory for Sustainable Chemistry at Interfaces' and 'Joint Laboratory for Natural Products and Synthesis towards Affordable Health'.

\section{References}


1 (a) S. I. Kirin, D. Wissenbach and N. Metzler-Nolte, New J. Chem., 2005, 29, 1168; (b) B. Lal, A. Badshah, A. A. Altaf, N. Khan and S. Ullah, Appl. Organomet. Chem., 2011, 25, 843; (c) S. Martić, M. Labib, P. O. Shipman and H.-B. Kraatz, Dalton Trans., 2011, 40, 7264.

2 (a) J. M. Casas-Solvas, E. Ortiz-Salmerón, J. J. GiménezMartínez, L. García-Fuentes, L. F. Capitán-Vallvey, F. SantoyoGonzález and A. Vargas-Berenguel, Chem. Eur. J., 2009, 15, 710; (b) C. Förster, M. Kovačević, L. Barišić, V. Rapić and K. Heinze, Organometallics, 2012, 31, 3683.

3 (a) D. Scutaru, L. Tataru, I. Mazilu, M. Vata, T. Lixandru and C. Simionescu, Appl. Organomet. Chem., 1993, 7, 225; (b) M. M. Abd-Elzaher and I. A. I. Ali, Appl. Organomet. Chem., 2006, 20, 107; (c) R. Trivedi, S. B. Deepthi, L. Giribabu, B. Sridhar, P. Sujitha, C. Ganesh Kumar and K. V. S. Ramakrishna, Appl. Organomet. Chem., 2012, 26, 369; (d) K. N. Tiwari, J.-P. Monserrat, A. Hequet, C. Ganem-Elbaz, T. Cresteil, G. Jaouen, A. Vessières, E. A. Hillard and C. Jolivalt, Dalton Trans., 2012, 41, 6451; (e) N. S. Radulović, M. Z. Mladenović, Z. StojanovićRadić, G. A. Bogdanović, D. Stevanović and R. D. Vukićević, Mol. Divers., 2014, 18, 497.

4 (a) K. Kowalski, J. Skiba, L. Oehninger, I. Ott, J. Solecka, A. Rajnisz and B. Therrien, Organometallics, 2013, 32, 5766; $(b)$ G. Jaouen, A. Vessières and S. Top, Chem. Soc. Rev., 2015, 44, 8802.

5 (a) S. I. Kirin, H.-B. Kraatz and N. Metzler-Nolte, Chem. Soc. Rev., 2006, 35, 348; (b) S. Chowdhury, G. Schantte and H.-B. Kraatz, Angew. Chem. Int. Ed., 2008, 47, 7056; (c) T. Moriuchi and T. Hirao, Acc. Chem. Res., 2010, 43, 1040.

6 R. Sun, L. Wang, H. Yu, Z.-u. Abdin, Y. Chen, J. Huang and R. Tong, Organometallics, 2014, 33, 4560.

7 (a) I. R. Butler, Eur. J. Inorg. Chem., 2012, 2012, 4387; (b) D. Schaarschmidt and H. Lang, Organometallics, 2013, 32, 5668; (c) N. A. Butt, D. Liu and W. Zhang, Synlett, 2014, 25, 615; (d) L. A. López and E. López, Dalton Trans., 2015, 44, 10128.

8 Á. Kuik, R. Skoda-Földes, J. Balogh and L. Kollár, J. Organomet. Chem., 2005, 690, 3237.

9 B. Breit and D. Breuninger, Synthesis, 2005, 2782.

10 J. C. Goeltz and C. P. Kubiak, Organometallics, 2011, 30, 3908.

11 J. C. Anderson, A. J. Blake and J. C. Arnall-Culliford, Org. Biomol. Chem., 2003, 1, 3586.

12 J. S. Skotnicki, R. M. Kearney and A. L. Smith, Tetrahedron Lett., 1994, 35, 197.

13 J. Banfić, A. A. Legin, M. A. Jakupec, M. Galanski and B. K. Keppler, Eur. J. Inorg. Chem., 2014, 484.

14 G. Dayaker, A. Sreeshailam, F. Chevallier, T. Roisnel, P. Radha Krishna and F. Mongin, Chem. Commun., 2010, 46, 2862.

15 C. Bolm, K. Muñiz-Fernández, A. Seger, G. Raabe and K. Günther, J. Org. Chem., 1998, 63, 7860.

16 (a) A. Sreeshailam, G. Dayaker, F. Chevallier, T. Roisnel, P. Radha Krishna and F. Mongin, Eur. J. Org. Chem., 2011, 3715; (b) G. Dayaker, A. Sreeshailam, D. V. Ramana, F. Chevallier, T. Roisnel, S. Komagawa, R. Takita, M. Uchiyama, P. R. Krishna and F. Mongin, Tetrahedron, 2014, 70, 2102.

17 A. Rauf and H. Parveen, Eur. J. Lipid Sci. Technol., 2004, 106, 97.

18 N. G. Connelly and W. E. Geiger, Chem. Rev., 1996, 96, 877.

19 O. Hammerich, Methods for studies of electrochemical reactions. In: Organic Electrochemistry, 4th Edition (Eds: $\mathrm{H}$. Lund, O. Hammerich), M. M. Dekker, New York, Basel, 2001, pp. 95-182.

20 C. K. Mann and K. K. Barnes, Electrochemical Reactions in Nonaqueous Systems, Marcel Dekker Inc, New York, 1970.

21 (a) J. D. Carr, L. Lambert, D. E. Hibbs, M. B. Hursthouse, K. M. A. Malik and J. H. R. Tucker, Chem. Commun., 1997, 1649; (b) S. R. Collinson, J. H. R. Tucker, T. Gelbrich and M. B.
Hursthouse, Chem. Commun., 2001, 555; (c) T. Moriuchi, K. Yoshida and T. Hirao, Org. Lett., 2003, 5, 4285; (d) J. Westwood, S. J. Coles, S. R. Collinson, G. Gasser, S. J. Green, M. B. Hursthouse, M. E. Light and J. H. R. Tucker, Organometallics, 2004, 23, 946.

22 (a) S. Chandrasekhar, M. S. Reddy, B. Jagadeesh, A. Prabhakar, M. H. V. R. Rao and B. Jagannadh, J. Am. Chem. Soc., 2004, 126, 13586; (b) B. Jagadeesh, M. U. Kiran, A. Sudhakar and S. Chandrasekhar, Chem. Eur. J., 2009, 15, 12592; (c) P. S. Mainkar, C. Sridhar, A. Sudhakar and S. Chandrasekhar, Helv. Chim. Acta, 2013, 96, 99.

23 H. E. Gottlieb, V. Kotlyar and A. Nudelman, J. Org. Chem., 1997, 62, 7512

24 A. Altomare, M. C. Burla, M. Camalli, G. L. Cascarano, C. Giacovazzo, A. Guagliardi, A. G. G. Moliterni, G. Polidori and R. Spagna, J. Appl. Crystallogr., 1999, 32, 115.

25 G. M. Sheldrick, Acta Crystallogr., Sect. A, 2008, A64, 112.

26 L. J. Farrugia, J. Appl. Crystallogr., 2012, 45, 849.

27 N. Marquise, F. Chevallier, E. Nassar, M. Frédérich, A. Ledoux, Y. S. Halauko, O. A. Ivashkevich, V. E. Matulis, T. Roisnel, V. Dorcet and F. Mongin, Tetrahedron, 2016, 72, 825. 